\title{
Transgenesis in Animals: Principles and Applications - A Review
}

\author{
Sheikh Firdous Ahmad ${ }^{*}$, Kanika Mahajan², Tania Gupta ${ }^{3}$, \\ Maliha Gulzar ${ }^{4}$ and Vandana Yadav ${ }^{5}$
}

\author{
${ }^{1}$ Division of Animal Genetics, ICAR-Indian Veterinary Research Institute, \\ Izatnagar, Bareilly (UP) - 243 122, India \\ ${ }^{2}$ Division of Livestock Products Technology, FVSc \& AH, SKUAST-J, Jammu - 180 009, India \\ ${ }^{3}$ Department of Veterinary Microbiology, Dr GC Negi College of Veterinary and Animal \\ Sciences, Palampur, Himachal Pradesh - 196 062, India \\ ${ }^{4}$ Department of Veterinary Public Health, FVSc \& AH, SKUAST-K, Shuhama, Srinagar, \\ $J \& K-190006$, India \\ ${ }^{5}$ Animal Genetics \& Breeding Division ICAR-National Dairy Research Institute Karnal, \\ Haryana - 132 001, India \\ *Corresponding author
}

\section{A B S T R A C T}

\section{Keywords}

Ethics, Regulation,

rDNA, Transgene,

Xenotransplantation

Article Info

Accepted:

24 September 2018

Available Online:

10 October 2018
Transgenesis refers to the technique involving the manipulation of genes of one organism and deliberate addition into the genome of another organism of same or other species and sometimes specific inhibition of endogenous gene inhibition. Transgenesis promises to solve different problems. The animals produced through the process of transgenesis will serve us various purposes from medicinal to commercial uses. Different methods of producing transgenic animals are available; however, their effectiveness varies with species involved. Various kinds of transgenic animals have been produced to date. However, few issues related to ethics and regulations of transgenic animals remain to be addressed. In this review, we tried to cover the basics of transgenics to understand their promise in the livestock world.

\section{Introduction}

With an ever-increasing population, there is increased pressure on available food resources and a constant threat to the food security. With shrinking agricultural land along with the recent figures and reports showing huge numbers of malnourished and starved people all over the world, the problem is escalating. Presently, as per the global organization (WHO) figures, over 795 million people are undernourished all over the world (FAO, 2015). On one hand, the revolutions in terms of green and white ones during the early 70s and 80 s have already reached their ceiling effects. At the other side, conventional breeding programmes have inherent problems such as being time-consuming and difficult to implement. Furthermore, conventional breeding is possible only between individuals of same or closely related species because of different reasons (including mechanical, 
temporal and behavioural isolation mechanisms). In some species, it may take 510 years (sometimes, even 20 years) to make up one generation and that is too much of a burden in the present world.

Intervention, through biotechnological techniques, seems to be an apparent answer to majority of these problems. The field of genetic engineering started long back in the 1980s but has, thereafter, progressed at a rapid pace. Biotechnological research is important as our response to ever-increasing pressure of the growing population as it will certainly help in relieving some pressure off these unspoken creatures. Transgenesis holds the promise to cover the inadequacies of conventional breeding programmes. Transgenesis refers to the technique involving the manipulation of genes of one organism and deliberate addition into the genome of another organism of same or other species and sometimes specific inhibition of endogenous gene inhibition (Shankar and Mehendale, 2014). This addition should be in a specific way that the genes thus introduced are not only introduced but also transmitted to the next generation(s). Recombinant DNA (rDNA) technology is an associated technology used to separate and construct the gene of interest producing the desired trait in the recipient animal (Shankar and Mehendale, 2014). When a gene construct gets integrated and inherited into the genome of recipient organism, it is called a transgene and the coded product (whether protein or others) thus produced is known as the transgenic product. In this review, we tried to give a basic understanding of various aspects of transgenesis in livestock from its theoretical to practical aspects.

\section{Transgenesis: Solution to problems}

The very biochemical composition of DNA and its regulation is manifested to be the same in all eukaryotic species (Magnus and Lali,
2008). Thus, intermingling the genetic content and producing a virtual mosaic is possible now. The exhaustive work is done in genetics, genomics and other branches of biotechnology, particularly the result of human genome project (along with its extension to other fields) opened vast areas in medical research in combination with transgenics (Jaenisch and Mintz, 1974). Transgenesis brought, with it, a revolutionary technology that involves introducing new genes to a species, which belong to an entirely different species (Magnus and Lali, 2008). In fact, with this technology, the door for gene transfer even across different kingdoms is possible. It promises to open vast areas into the scientific world and this ultimately will have a positive impact on human welfare (Melo et al., 2007).

\section{Transgenesis in livestock}

The use of genetic engineering for the improvement of livestock was pioneered by Palmiter et al., (1982). Though the initial success of this technology in terms of transgenesis was obtained in laboratory animal mice in 1974 by Jaenisch and colleagues, the success in larger animals was obtained only in 1997 when first successful transgenic cattleRosie, was generated (Clarke, 2002).

Through genetic engineering, it is possible to make specific alterations to animals' genome that seems and is impossible to achieve through conventional selective breeding. In the present scenario, we easily think of manipulating the properties of animals; be that with meat, milk, egg, wool, excretory products, other behavioral, psychological, physiological or any other responses (Pusta, 2011). In fact, one of the first applications of these transgenically produced large farm animals was that they could produce altered or novel proteins in their milk (Van Berkel et al., 2002) 
The process of transgenesis with the production of transgenic animals promises following general advantages:

Increased growth rate in meat animals (Beef, pigs, chicken, etc)

Increased muscle mass

Increased feed conversion rates

Improved nutritional quality

Increased disease resistance in animals

Improved wool quality

Disease models

Xenotransplantation

Bioreactors

However, with transgenesis, it is not the end for conventional animal breeding procedures, but these two processes will need to be taken in conjunction for better animal production. These aspects include that of feed optimization, reproductive improvement, disease control, efficient production alongside other common goals (Houdebine, 2002).

\section{Methods of production of transgenic animals}

The establishment of stable transgenic animals obviously implies that the foreign DNA is inserted and gets transmitted to the progeny(ies). To serve this purpose, the transgene needs to be integrated into gametes or one-cell embryos. Initially, only a few methods of production of transgenic animals were available; however, considerable progress has already been made in these methods as many methods are now available with the scientists. The production of transgenic animals embarked with the method of pronuclear microinjection over 20 years ago. New methods followed it, including those of viral vectors, sperm-mediated gene transfer and somatic cell cloning. Each new method has added a feather and helped to overcome many of the limitations of earlier methods. Different methods of production are preferable in different animal species. It seems now relatively easy to readily make simple insertional genetic modifications into these animals' genome. Following is a brief account on main methods for production of transgenic animals:

\section{DNA Microinjection}

This method includes the direct DNA microinjection into the pro-nuclei of embryos and was the first documented technique that helped in the initiation of transgenesis concept. As this remained the only protocol in earlier times, it was followed in all species of animals and results differed with a decreasing yield in terms of successful animals produced from mouse to cow. Large farm animals including bovine animals have a slow reproduction rate and the embryo generation under superovulation is comparatively low. The success seemed accessible only after invitro preparation cum maturation on matured oocyte if embryos were prepared in vitro after oocyte maturation and fertilization followed by in vitro development of the microinjected to the blastocyst stage (Krimpenfort et al., 1991). The method is laborious and costly and its success in various species remains variable due to unknown reasons. The first transgenic livestock was produced in 1985 by microinjection of foreign DNA into zygotic pronuclei.

\section{The use of transposons}

In several animal species, it may be difficult to integrate injected foreign DNA from the cytoplasm directly into the genome. It remains to be the main problem associated with producing transgenic poultry. Intended to counter this limitation and increase the frequency of integration, several tools and techniques were tried and implemented from time to time. One way of making this a reality is by generating breaks in host DNA. This is 
done by injecting low amounts of restriction enzymes that help cut it at specific regions. The DNA repair mechanism restores DNA and integrates the foreign DNA into the genome of an animal. This method is analogous to gene editing in cells for various purposes wherein the inherent repair mechanism of cells is exploited. Low concentrations of restriction enzyme have no significant effect whereas the same is not true with the higher enzyme concentrations.

\section{Retrovirus-mediated gene transfer}

The success rate of transgenesis by any method has been limited due to the efficiency of gene transfer. Among the several gene transfer systems available, retrovirus-mediated gene transfer has been highly efficient (Nowrouzi et al., 2011). Retroviruses are used as vectors to transfer gene efficiently due to their affinity and infectivity for certain target cells resulting in successful transgene incorporation (Koo et al., 2014). Retrovirus transfers genetic material in the form of RNA into the host cells resulting in the generation of chimera. The chimeras are thereafter inbred for nearly 20 generations to obtain homozygous transgenic offspring which carries the desired transgene in each cell (Manmohan and Niraj, 2010). This method was used successfully in the production of transgenic mice in 1974 using the simian virus.

\section{Embryonic stem cell-mediated (ESC) gene transfer}

The ESC method involves prior insertion of the target DNA sequence into in vitro culture of embryonic stem cells by homologous recombination. Embryonic stem cells are pluripotent and derived from the inner cell mass of a blastocyst that has the potential to differentiate into any type of cell such as somatic cells and hence leads to the creation of complete organism. Embryonic stem cells are used for more accurate alterations of the mouse genome. This technique allows insertion, removal or modification of DNA sequences. Knock-out, knock-in and conditional mutant mice are produced with this method (Buy, 1997). The mouse produced initially from such cell injections is a genetic chimera composed of embryonic stem derivatives and cellular descendants of the blastocysts into which the embryonic stem cells are inserted.

\section{Lentiviral Transfer of Oocytes and Zygotes}

This method helps overcome the drawback of viral-mediated gene transfer which includes silencing of the transgenic locus and low expression levels. An example includes the generation of transgenic cattle by lentiviruses involves microinjection into the oocytes (Hofmann et al., 2004). In this, lentivirusbased vectors used can infect non-dividing cells, carry large amounts of the transgene $(10 \mathrm{~kb})$ and depict stable expression in the tissue in which they are incorporated. This technique has shown successful results with a 100 fold increase in the level of transgenesis (Sang, 2004).

\section{Potential, promises and concerns}

Transgenesis in the animal world (and other fields) continues to excite and elicit excitement in scientifically tempered minds. It is one of the most potent and exciting fields of the present biological sciences. It promises to provide pivotal tailored models for various kinds of research that are ultimately aimed at the welfare of society as a whole (through its various uses). They also have the potential to answer and address some special biological problems. The use of transgenic animals also promises us to decipher complex biological process and systems that may have hampered our progress until now (Pinkert, 2014). The 
use of transgenesis process is itself of immense significance in those animal species whose life cycle and generation interval reduces the effectiveness of conventional breeding practices for rapid genetic improvement.

Transgenic animal models once prepared shall provide us with to provide us the scope for unimaginable control over the genetic makeup of an organism/animal aimed eventually to visualize varied gene products (Shankar and Mehendale, 2014). Due to this unprecedented property and versatility of transgenic models, they are presently the mainstay of biomedical and research landscapes. It emerges out to be a well-established fact now that transgenesis is one of the prime tools of biologists to study gene expression and function. Transgenesis is extensively and systematically being used in the identifying and deciphering the function of different human genes. The technique of transgenesis promises a helping hand in many aspects of biological sciences including genetic research, epigenetic studies, immune and cancer research, pharming, biomedicine and agriculture along with various other fields.

Scientific studies on systems of neurology, cardio-vascular system, thyroid function and dysfunction, intermediary metabolism, hemoglobin switching and reproduction are some other fields where transgenic animals are of immense help (Blundell, 2006) Furthermore, it will undoubtedly help in the genetic improvement of our livestock (Wheeler et al., 2003).

Transgenic animal production is aimed to produce models for various diseases including genetic/developmental defects, neoplastic, metabolic, nutritional, degenerative and infectious ones (Blundell, 2006). The very productive and efficient application of transgenesis in the animal world has opened vast areas into our understanding of the gene function and regulation (Wolfgang, 2016). While most of the research till very recent times was restricted to be done on mice and other lab animals, now this is sure to extend to other complex biological systems of large animals. Transgenic farm animal models for various diseases are said to provide better models than genetically modified animals like mice and rats.

The diseases, affecting the human population, for which successful models have been prepared, are sickle cell anemia, prostatic hyperplasia, diabetes mellitus, retinoblastoma, learning impairment and cystic fibrosis (Blundell, 2006). Transgenic rabbits are being used in research and studies on the disease known to us as atherosclerosis. This ultimately will help in basic understanding and mechanism studies on this disease (Taylor, 1997). Transgenic non-human primates i.e. Monkey, similar to humans in various aspects, is used in clinical trials for HIV and Huntington's chorea (Yang et al., 2008).

Presently the species for which transgenic varieties have been prepared are mice, goat, sheep, chicken, cow, horse, dogs, fishes, swine, monkeys and various other ones (Clark and Pazdemik, 2016). It is nothing but obvious, that these transgenic animals fulfill various purposes to their producers, caretakers and society as well. Milk, meat, egg white, blood, urine, seminal plasma, silkworm cocoon along with others form preferred routes to be the source(s) of recombinant proteins at commercial scale (Houdebine, 2002). On one side, a transgenic cow produces milk with increased casein content in it and on the other hand milk from goat has increased anti-thrombin content which is extremely useful in hemophiliac individuals and several other conditions (Umaraw et al., 2015). Some other instances of transgenic animals include that of transgenic sheep 'Tracy' being aimed for efficient and woolier output. 
Table.1 Transgenic animals produced to date along with their uses

\begin{tabular}{|c|c|c|c|}
\hline S. No & $\begin{array}{l}\text { TRANSGENIC } \\
\text { ANIMAL }\end{array}$ & USE & Scientist/University \\
\hline 1. & $\begin{array}{l}\text { Ruppy } \\
\text { (The Glowing } \\
\text { transgenic Puppy) }\end{array}$ & Model to study human diseases. & $\begin{array}{l}\text { Byeong-Chun Lee (Seoul } \\
\text { National University in South } \\
\text { Korea) }\end{array}$ \\
\hline 2. & Spider-goat & $\begin{array}{l}\text { Spider silk protein in its milk is } \\
\text { used in various products such as } \\
\text { artificial ligaments, wound } \\
\text { dressings, body armor, implantable } \\
\text { optical systems for medicine. }\end{array}$ & $\begin{array}{l}\text { Randy Lewis (University of } \\
\text { Wyoming) }\end{array}$ \\
\hline 3. & Enviropig & $\begin{array}{l}\text { To mitigate the problem of manure } \\
\text { based environmental pollution by } \\
\text { efficiently utilizing plant } \\
\text { phosphorus. }\end{array}$ & $\begin{array}{l}\text { Meidinger et al., } 2013 \\
\text { (University of Guelph) }\end{array}$ \\
\hline 4. & $\begin{array}{l}\text { Herman } \\
\text { (Transgenic Cow) }\end{array}$ & $\begin{array}{l}\text { Produces human protein lactoferrin } \\
\text { in its milk that can be useful in } \\
\text { developing various medications. }\end{array}$ & Gen Pharm International \\
\hline 5. & $\begin{array}{l}\text { ANDi } \\
\text { (Transgenic } \\
\text { Monkey) }\end{array}$ & $\begin{array}{l}\text { Biological model of research and } \\
\text { thus useful for curing of nearly } \\
\text { ineffable diseases. }\end{array}$ & $\begin{array}{l}\text { A. W. S. Chan and his } \\
\text { colleagues (Oregon Regional } \\
\text { Primate Research Center) }\end{array}$ \\
\hline 6. & $\begin{array}{l}\text { Salmon } \\
\text { (Transgenic fish) }\end{array}$ & $\begin{array}{l}\text { Grows rapidly with the ability to } \\
\text { continuously produce growth } \\
\text { hormone. }\end{array}$ & Devlin et al., 2001. \\
\hline \multicolumn{4}{|c|}{ Transgenic Mice } \\
\hline 7. & Marathon Mouse & $\begin{array}{l}\text { Useful in designing drugs that } \\
\text { enhance muscle development and } \\
\text { mimic all the merits of exercise. }\end{array}$ & $\begin{array}{l}\text { Howard Hughes Medical } \\
\text { Institute }\end{array}$ \\
\hline 8. & Oncomouse & $\begin{array}{l}\text { Useful test subjects for cancer } \\
\text { research }\end{array}$ & $\begin{array}{l}\text { Philip Leder and Timothy } \\
\text { Stewart(Harvard University) }\end{array}$ \\
\hline 9. & Mighty Mice & $\begin{array}{l}\text { Model to study various aspects of } \\
\text { ageing. }\end{array}$ & $\begin{array}{l}\text { Dr. Richard Hanson (Case } \\
\text { Western University) }\end{array}$ \\
\hline 10. & AIDS mouse & $\begin{array}{l}\text { Model to study and develop a cure } \\
\text { for HIV infection. }\end{array}$ & $\begin{array}{l}\text { Researchers at the University } \\
\text { of Maryland(2001) }\end{array}$ \\
\hline 11. & Alzheimers mouse & $\begin{array}{l}\text { To develop vaccine against } \\
\text { Alzheimer's disease. }\end{array}$ & $\begin{array}{l}\text { Joint efforts of researchers at } \\
\text { Worcester polytechnic } \\
\text { institute and Transgenic } \\
\text { Sciences Inc.(1995) }\end{array}$ \\
\hline 12. & Youth Mouse & $\begin{array}{l}\text { Model to study ageing, diets and } \\
\text { clot dissolution. }\end{array}$ & $\begin{array}{l}\text { Researchers of Weizmann } \\
\text { Institute of science }\end{array}$ \\
\hline 13. & $\begin{array}{l}\text { Smart } \\
\text { Mouse/Doggie }\end{array}$ & $\begin{array}{l}\text { Gene inserted improves the } \\
\text { memory of mice which could be } \\
\text { beneficial to the society in near } \\
\text { future. }\end{array}$ & $\begin{array}{l}\text { Researchers at Princeton } \\
\text { University }\end{array}$ \\
\hline
\end{tabular}


With transgenesis, cows are now known to produce more milk or milk with an altered composition such as less lactose or cholesterol; pigs and cattle have more meat on them that is also rapidly growing and sheep get woolier. Pigs with the intentional addition of human IGF 1 produce 30 percent more loin mass, 10 percent more carcass lean tissue and 20 percent less carcass fat (Pursel et al., 2004). "Healthy Pork" is produced from transgenic pigs that carry a gene from plant origin and this pork has increased amount of unsaturated fatty acids (which is not present normally in them) in it (Niemann, 2004)

Transgenic animals are also potentially useful in the production of various medicines, nutritional supplements and pharmaceuticals besides several other uses. With the combined use of nutritional, genetic and biotechnological concepts, researchers have gained significant success in the production of 'medicine milk', that will be rich in specific milk components. This, in turn, will have significant implications for health and treatment aspects. Ruminants such as cows, goats and sheep are being utilized for the production around 60 therapeutic proteins including those of plasma proteins, monoclonal antibodies and vaccines (Masih et al., 2014)

Another instance of transgenesis being helpful to humans is that of transgenic pigs that are very useful in the process of xenotransplantation. They can donate different organs with minimum complications and efficient results (Melo, 2007). They are also used in the study of human co-factor proteins. Livestock species have long provided tissues or tissue extracts for treatment of human illness. Pig hearts, for example, have provided valves for transplantation. The transgenic approach has embarked several possibilities with it in providing tissues or tissue extracts for transplantation into humans. Swanson et al., (1992) documented research shows the production of functional human hemoglobin in transgenic swine, although a number of limiting factors exist. These organ(s) from transgenic animals are so modified that no host immune response is elicited, and thus no problem of rejection occurs.

In the pharmacy sector, with genetic engineering and transgenesis, the gene responsible for any drug of interest can be transferred into other desired animal that will produce large amounts of that drug. This technology is popularly known as pharming that involves the production of human pharmaceuticals from animals on a large scale. With gene "Pharming", we are able to produce recombinant and biologically active proteins in various organ systems of transgenic animals. In transgenic ruminants, the milk secretion route from the mammary glands is most preferable and used. The quality of protein(s) that are produced in this organ is efficient as there are specific promoter elements and methods are established for extraction and purification of those proteins (Magnus and Lali, 2008).

Preparation of biochemical and other hormones is also underway, which is mostly targeted to produce some important hormones such as insulin, growth hormone and blood anti-clotting factors. Variable progress has already been made in the production of these products from transgenic cows, sheep or goats and others. Research is also underway to target to counter other diseases like phenylketonuria (PKU), hereditary emphysema, and cystic fibrosis by applying the path of transgenesis.

Production of monoclonal antibodies is another important aspect of transgenic animals. Numerous monoclonal antibodies are being produced from the mammary gland of transgenic goats. Transgenic cattle produce 
specific recombinant bispecific antibodies in their blood. The stable antibody thus purified from blood mediates target cell restricted T-cell stimulation and tumor cell killing.

An exotic protein in the form of spider silk, that is known to possess exceptional mechanical properties, has recently been obtained from mouse milk (Karatzas et al., 1999). In the production of silk-producing goats, scientists added cells originated from silk spiders to the genome of goats. The transgenic goats thus formed started producing strands of silk in their milk. The silk is strong, lightweight and is used to make clothing and other items. Spider silk is described as "ancient biomaterial of the future" by Professor Randy Lewis of Utah State University. In the medical field, research work suggests that spider silk is virtually invisible to our immune system and it thus won't reject it. This, in turn, makes spider silk, due to its elastic and tensile properties, a perfect substitute for its use as artificial tendons, cartilage and ligaments as well as suture material and sealants. In warfare, a layered piece of rubbery silicon with about 10 layers of spider silk painted on it was seen enough to stop a bullet because of its incredible absorbent qualities for dissipating impact and shock. Spider silk also finds uses in various other fields.

Still, the question remains which animal to be used for the purpose of transgenesis or else if all animals are the same in this regard? Variation amongst various mammalian species is distinct in terms of size and other parameters and several of them have been successfully manipulated to produce recombinant proteins in their milk. Small ruminants such as sheep and goat have emerged as the best animals for the production of proteins up to several tons per year. The pig now stands confirmed as living fermentor although milk cannot easily be collected from it as in ruminants. The rabbit is said to produce about $200-250 \mathrm{ml}$ of milk per day that is rich in protein. Transgenic rabbits are easy to produce and at a relatively low cost. Rabbits are prolific breeders and are fit for production of recombinant proteins not exceeding $1 \mathrm{~kg}$ per year. On the other hand, transgenic cattle bear a potential to produce 400 tons of human albumin per year (Blundell, 2006). Table 1 summarizes the different transgenic animals produced to date along with their uses.

However, the field of transgenesis is not a perfect science and does not come without any negatives. It is seen in a certain number of cases that recombinant proteins produced from some organ systems pose deleterious threats, for say to mammary gland function, or to the animal as a whole. These effects may be visible in the present or the future aspects of the life of an animal. These effects are mainly attributed to some form of ectopic expression of the transgenes and to the probable transfer of recombinant proteins from milk to blood or other connecting systems. One documented possibility to counter and/or reduce these deleterious effects is to use induction molecules for the systems such as tetracycline. This will eventually allow transgenes to be expressed only during certain specified physiological period say lactation period and will also strictly limit its expression into one system only say mammary gland. The procedure of these recombinant proteins is generally not very difficult, particularly from milk. This, however, may not be the situation with endogenous proteins such as serum albumin or antibodies that are present abundantly in milk. The physiological occurrence of these proteins in the blood may be a crucial factor for creating problems with their production. Among the various biological contaminants potentially (not always and not proven) present in some recombinant proteins from transgenic animals, prions are certainly those raising the major concern. Besides these, there are several legal, ethical and social issues that are an integral part of transgenesis and associated with its introduction in the livestock world. These ethical, legal and social aspects of biotechnological research need to be addressed before the implementation of transgenic herds. Overexpression and unregulated expression are other concerns associated with the field of transgenesis. 
It may well be concluded that the field of transgenesis has developed rapidly and promises to solve many problems of the present world. Its applications in livestock are immense but word of caution is important. Before the commercial application in regulated mode, few issues (such as legal and ethical issues) will need to be addressed.

\section{Acknowledgements}

The authors would like to thank ICAR to provide the necessary facilities and JRF fellowship during this study.

\section{Conflict of interest}

The authors declare no conflict of interest for this manuscript

\section{References}

Blundell, R. 2006. Transgenic Animals-Review Paper. Journal of Animal and Veterinary Advances, 5(11), 935-938.

Buy, M. 1997. Transgenic Animals, Animal Welfare and Ethics, Canadian Council on Animal Care (CCAC). Retreived from https://people.ucalgary.ca/ browder/guide lines.html/.

Clark, D. P. and Pazdernik, N. J. 2016. Nanobiotechnology. Biotechnology, 219248.

Clarke, A. R. 2002. Transgenesis techniques: principles and protocols (Vol. 180). Springer Science \& Business Media.

Devlin, R. H., Biagi, C. A., Yesaki, T. Y., Smailus, D. E. and Byatt, J. C. 2001. Growth of domesticated transgenic fish. Nature, 409(6822), 781.

FAO, I. (2016). WFP (2015), The State of Food Insecurity in the World 2015. Meeting the 2015 international hunger targets: taking stock of uneven progress. Food and Agriculture Organization Publications, Rome.

Hofmann, A., Zakhartchenko, V., Weppert, M., Sebald, H., Wenigerkind, H., Brem, G. and Pfeifer, A. 2004. Generation of transgenic cattle by lentiviral gene transfer into oocytes. Biology of Reproduction, 71(2), 405-409.

Houdebine, L. M. 2002. Animal transgenesis: recent data and perspectives. Biochimie, 84(11), 11371141.

Houdebine, L. M. 2002. Transgenesis to improve animal production. Livestock Production Science, 74(3), 255-268.

Jaenisch, R. and Mintz, B. 1974. Simian virus 40 DNA sequences in DNA of healthy adult mice derived from preimplantation blastocysts injected with viral DNA. Proceedings of the national academy of sciences, 71(4), 1250-1254.

Karatzas, C. N., Zhou, J. F., Huang, Y., Duguay, F., Chretien, N., Bhatia, B. and Wang, B. 1999. Production of recombinant spider silk (Biosteel TM) in the milk of transgenic animals. Transgenic Res, 8, 476-477.

Koo, B. C., Kwon, M. S. and Kim, T. 2014. Retrovirus-mediated gene transfer. In Transgenic Animal Technology (Third Edition) (pp. 167-194).

Krimpenfort, P., Rademakers, A., Eyestone, W., van der Schans, A., van den Broek, S., Kooiman, P. and de Boer, H. 1991. Generation of transgenic dairy cattle using 'in vitro' embryo production. Nature Biotechnology, 9(9), 844.

Magnus, P. K. and Lali, F. A. 2008. Transgenic milk. Veterinary World, 1(10), 319.

Manmohan, S. and Niraj, K. 2010. Transgenic animals: production and application. International Journal of Pharmaceutical Sciences and Research (IJPSR), 1(9), 12-22.

Masih, S., Jain, P., El Baz, R. and Khan, Z. K. 2014. Transgenic Animals and their Applications. In Animal Biotechnology (pp. 407-423).

Meidinger, R. G., Ajakaiye, A., Fan, M. Z., Zhang, J., Phillips, J. P. and Forsberg, C. W. 2013. Digestive utilization of phosphorus from plant-based diets in the Cassie line of transgenic Yorkshire pigs 
that secrete phytase in the saliva. Journal of animal science, 91(3), 1307-1320.

Melo, E. O., Canavessi, A. M., Franco, M. M. and Rumpf, R. 2007. Animal transgenesis: state of the art and applications. Journal of applied genetics, 48(1), 47-61.

Niemann, H. 2004. Transgenic pigs expressing plant genes. Proceedings of the National Academy of Sciences, 101(19), 72117212.

Nowrouzi, A., Glimm, H., Von Kalle, C. and Schmidt, M. (2011). Retroviral vectors: post entry events and genomic alterations. Viruses, 3(5), 429-455.

Palmiter, R. D., Brinster, R. L., Hammer, R. E., Trumbauer, M. E., Rosenfeld, M. G., Birnberg, N. C. and Evans, R. M. 1982. Dramatic growth of mice that develop from eggs microinjected with metallothionein-growth hormone fusion genes. Nature, 300(5893), 611.

Pinkert, C. A. 2014. Introduction to Transgenic Animal Technology. In Transgenic Animal Technology (Third Edition) (pp. 3-13).

Pursel, V. G., Mitchell, A. D., Bee, G., Elsasser, T. H., McMurtry, J. P., Wall, R. J. and Schwartz, R. J. 2004. Growth and tissue accretion rates of swine expressing an insulin-like growth factor I transgene. Animal biotechnology, 15(1), 33-45.

Pusta, D. 2011. Animal Transgenesis and its Applications. Bulletin of University of Agricultural Sciences and Veterinary Medicine Cluj-Napoca. Veterinary Medicine, 67(1).

Sang, H. M. 2004. Transgenics, chickens and therapeutic proteins. Voxsanguinis, 87, 164-166.
Shankar, K. and Mehendale, H. M. 2014. Transgenic Animals (Third edition), pp. 802-803.

Swanson, M. E., Martin, M. J., O'Donnell, J. K., Hoover, K., Lago, W., Huntress, V. and Logan, J. S. 1992. Production of functional human hemoglobin in transgenic swine. Nature Biotechnology, 10(5), 557.

Taylor, J. M. 1997. Transgenic Rabbit Models for the Study of Atherosclerosisa. Annals of the New York Academy of Sciences, 811(1), 146-154.

Umaraw, P., Verma, A. K. and Kumar, D. 2015. Designer Milk-A Milk of Intrinsic Health Benefit: A Review. Journal of Food Processing \& Technology, 6(3), 1.

Van Berkel, P. H., Welling, M. M., Geerts, M., van Veen, H. A., Ravensbergen, B., Salaheddine, M. and Nibbering, P. H. 2002. Large scale production of recombinant human lactoferrin in the milk of transgenic cows. Nature biotechnology, 20(5), 484.

Wheeler, M. B., Walters, E. M. and Clark, S. G. (2003). Transgenic animals in biomedicine and agriculture: outlook for the future. Animal reproduction science, 79(3-4), 265-289.

Wolfgang, M. J. 2016. Transgenesis and Gene Replacement. In Encyclopedia of Cell Biology, pp. 512-516.

Yang, S. H., Cheng, P. H., Banta, H., Piotrowska-Nitsche, K., Yang, J. J., Cheng, E. C. and Fang, Z. H. 2008. Towards a transgenic model of Huntington's disease in a non-human primate. Nature, 453(7197), 921.

\section{How to cite this article:}

Sheikh Firdous Ahmad, Kanika Mahajan, Tania Gupta, Maliha Gulzar and Vandana Yadav. 2018. Transgenesis in Animals: Principles and Applications - A Review. Int.J.Curr.Microbiol.App.Sci. 7(10): 3068-3077. doi: https://doi.org/10.20546/ijcmas.2018.710.358 